\title{
The Environmental Dimension of Groundwater in Brazil: Conflicts between Mineral Water and Water Resource Management
}

\author{
Ana Lucia Desenzi Gesicki', Francesco Sindico² \\ ${ }^{1}$ National Department of Mineral Production (DNPM), Superintendence of São Paulo, São Paulo, Brazil \\ ${ }^{2}$ Strathclyde Centre for Environmental Law and Governance (SCELG), University of Strathclyde, Glasgow, UK \\ Email: ana.gesicki@dnpm.gov.br, francesco.sindico@strath.ac.uk
}

Received 13 September 2014; revised 8 October 2014; accepted 1 November 2014

Copyright (C) 2014 by authors and Scientific Research Publishing Inc.

This work is licensed under the Creative Commons Attribution International License (CC BY). http://creativecommons.org/licenses/by/4.0/

(c) (i) Open Access

\begin{abstract}
There are three legal categories of groundwater in Brazil. Mineral water and potable table water are considered mineral resources, are part of the Federative Union's assets, and follow the legal regime applicable for the mining sector. "Normal" groundwater, on the other hand, falls under State's jurisdiction and is dealt within the Brazilian System of Water Resource Management, which promotes a decentralized and participatory management of water resources on surface or stored underground. This has led to conflicts of competences between federal (mining regulation) and state agencies (water resource management) because different concepts and styles of management are involved. This article argues for the urgent need to reopen the discussion aimed at a possible major revision of Brazilian mineral water legislation, in order to duly take into account the environmental dimension of groundwater as a public good for common use. An open-minded and transparent discussion involving the government and different sectors of society with competing interests in mineralized groundwater would therefore be highly recommended.
\end{abstract}

\section{Keywords}

Mineral Water, Water Resources, Mining Law, Water Policy, Brazil

\section{Introduction}

In spite of Brazil's continental land area and abundance of fresh water, the country faces challenging tasks in managing water resources due to significant regional diversity and inequity of water distribution within its terri- 
tory. While the sparsely populated northern portion of the country encompasses the largest river basin in the world (the Amazon river basin), the Northeast suffers from periodic droughts and the Southeast has to tackle with the issues of water resources having an unbalanced supply-demand relationship and increasing pollution due to urbanization and industrial activities [1] [2].

Regarding specifically Brazilian groundwater resources, these are subject to competing interests from various categories of use, mainly in the regions where the availability of surface fresh water of good quality is under threat from growing risk of pollution and scarcity due to critical climatic events. An overall estimate reveals that there must be about 400,000 wells across the country pumping groundwater for several purposes, at a likely total abstraction rate of $4000 \mathrm{~m}^{3} / \mathrm{s}$ [3]. This estimate still gives a wide margin for safe water use considering that renewable reserves of groundwater in Brazil have been estimated at about 42,000 $\mathrm{m}^{3} / \mathrm{s}$ [4].

The Brazilian Water Reform, carried out in the late 1990s, includes several principles and instruments internationally accepted for dealing with water resources, such as integrated and decentralized management and multiple uses of water. The water legislation, however, is silent on economic uses of mineralized groundwater. This is not surprising considering the aged legislation for mineral waters, namely Code of Mineral Waters (CMW), was enacted in 1945 and has never been updated. The CMW considers mineral water as a mineral substance with economic value and deals with it separately from water resource management. By doing so, mineral water falls under the same legal regime applicable for the mining sector. This has led mineral water and groundwater to be covered by different legal frameworks that embody distinct concepts and styles of management, which results in conflicts of competences between federal (mining regulation) and state agencies (water resource management).

Against this background, this article aims to critically assess the likely sources of conflicts between mineral water and water resource management, by providing an overview of both legal frameworks. This article is divided in six sections. The first three are devoted to provide an overview of the relevant aspects of the water, mining and environmental legislations in Brazil. The next two sections examine in detail the reasons why mineral water legislation is in disagreement with the principles of the mining sector and of water resource management, including a reported case of conflict of interests between federal and local institutions. The last section finally addresses key legal standpoints, which we consider important enough to justify a major revision of the current mineral water legislation.

\section{Water Resources-Principles and Policies}

Since the first decades of the 1900s, rivers have been extremely important in Brazil because of their huge potential to generate energy. As a result, Brazil's energy matrix relies heavily on hydroelectricity. The Water Code of 1934 represents the early efforts to discipline the use of water resources in a country with an increasing demand for energy due to the growth of an urban-industrialized society [1]. During more than 60 years, the Water Code played an important role in governing the use of surface water resources for hydropower generation purposes, but several provisions of the law related to other matters (for example, groundwater use) have never been properly regulated because the law did not take into account the complexity of different water uses. Although the Water Code is still in force, several provisions were implicitly revoked by the 1988 Federal Constitution. This has been the case for example, for water bodies previously ascribed as private property and municipal rivers.

The awareness for the need for environmental protection that emerged in the 1970s, combined with the further widespread understanding of the need to promote sustainable development, culminated in a change of paradigm from an ancient culture of disregard for available water to a new concept of water as a scarce resource [2]. The new environmental mind-set when dealing with water has led to a review of governmental strategies and actions for the implementation of an integrated management programme for water resources in Brazil [3]. The first step towards this achievement was the promulgation of the 1988 Federal Constitution itself, which assigned all waters to the public domain and mandated the implementation of the national system for water resource management. International legal instruments about water and the environment, such as the Dublin Declaration of 1992, reinforced the discussion about principles for water resource management and played an important role in the process of reviewing laws and policies at federal and state levels ${ }^{1}$. This led to the enactment of the National

\footnotetext{
${ }^{1}$ Porto and Kelman cite that for the law-making process, several workshops took place during the first half of the 1990s, involving a broad set of participants, such as politicians, water professionals, NGOs and local communities in order to reinforce the need for decentralization of water management and the need for counting on democratic participation by society [1].
} 
Water Act in 1997 (Law 9.433/1997), also known as "Water Law", which laid the basis for the National Policy for Water Resources and created the National System of Water Resource Management (SINGREH), launching new principles, objectives and administrative instruments for managing water resources in Brazil.

The National Policy for Water Resources is based on six principles that underpin the Brazilian system of water resource management. First, water is considered to be a public good, following constitutional mandatory provisions. Second, it is recognized that water is a limited resource with economic value. Third, in the case of water shortage, the law establishes priority water uses for human and animal consumption. Fourth, the multiple uses of water must be considered within the management of water resources. Fifth, it establishes the river basin as the basic territorial unit for the implementation of the National Policy for Water Resources and the National System of Water Resource Management. Sixth, the law promotes the decentralized and democratic management of water resources, counting on the participation of governmental institutions, stakeholders and communities involved in the river basins.

An important advance in Water Reform was the introduction of a permit system, at a national level, to grant rights for any use of water resources stored underground. As groundwater is under the exclusive jurisdiction of the States ${ }^{2}$, groundwater users must follow the rules established by the water permit system defined at State lev$\mathrm{el}^{3}$. For granting water rights, some relevant issues are observed by the State bodies, such as the water availability of the aquifer in the river basin, its expected recharge rate and the stipulation of a maximum yield for groundwater abstraction that is considered "sustainable", i.e. the volume of water in a rate of abstraction that guarantees the availability of groundwater for other uses [5]. The authorization for water use issued by the State institution is time limited, a time limit that varies from State to State ${ }^{4}$.

The dual jurisdiction over water bodies has been identified as a challenge for the integrated management of water resources. That is the case of surface waters, which can be under the jurisdiction of the Union or the States depending on their geographic localization ${ }^{5}$. It is not different for groundwater. Even though the Constitution defines the jurisdiction of groundwater to the States, there are not yet legal provisions to integrate mineralized groundwater management to the National Policy for Water Resources and so providing a desirable integration between federal and State agencies. For a country of great regional diversity, the governance of water resources depends primarily on the cooperation between the different levels of the government, which is not simple to achieve [3] considering that Union, States and Municipalities all have administrative autonomy to define rules and standards to deal with protection of the environment and other issues of their own competences.

\section{Protection of the Environment}

At the time when the legislation for mineral water was drafted, Brazil had great potential for development and was starting to face a significant increase in the rate of industrialization and also undergoing a population explosion, mainly in the southern urban centres. Paradoxically, this accelerated economic growth was founded on increasing regional economic discrepancies, and occurred at the expense of individual freedoms and furthermore imposed environmental costs because of the uncontrolled use of the country's natural resources [6]-[8].

The model of development at all costs started to be questioned in the 1970s, mainly as a result both of a movement of civil society organizations and of several serious environmental damages in Brazil ${ }^{6}$. Environmental regulation at federal level in Brazil started with the promulgation of Law 6.938/1981, which established the National Environmental Policy, and set up the National System for the Environment (SISNAMA) multi-institutional framework. Within SISNAMA there are institutions and entities at Federal, State and Municipal levels that grant environmental licenses, carry out inspections and enact supplementary rules and policies within the

\footnotetext{
${ }^{2}$ Article 26 of the 1988 Federal Constitution.

${ }^{3}$ Water permit systems vary in national range because States are allowed to promulgate their own legislation of water resource management, following the guidelines established in the National Policy for Water Resources. For this reason, there are States with long-term and well established water permit systems (e.g. São Paulo and Minas Gerais States) and others which have just promulgated its own water legislation and still face difficulties with the enforcement of the law.

${ }^{4}$ The maximum period of validity of water rights is 35 years.

${ }^{5}$ Surface fresh water bodies (rivers and lakes) are under the States' domain except if they serve as boundaries with other countries or between States, which are considered of federal jurisdiction.

${ }^{6}$ One of the most serious events of environmental damage occurred in Cubatão, an industrial city in São Paulo State, where uncontrolled pollution caused by 24 petrochemical and steel companies resulted in mountain landslides, contamination of soil, rivers and air, as well as grave health problems to local population. The companies were involved in a lawsuit filed under the Public Civil Action conducted by the State Public Ministry from 1985 and obliged to fully remediate the environment [9].
} 
ambit of their own competences in matters related to environmental protection and pollution control.

Environmental regulation of economic activities in Brazil stems on two internationally widespread principles: the precautionary and the polluter-pays principles. The precautionary principle requires a proactive approach towards the protection of the environment, using two main instruments of the National Environmental Policy - environmental impact assessment (EIA) and licensing of economic activities that cause potential or effective hazards to the environment ${ }^{7}$. The environmental viability of a project is analyzed by SISNAMA bodies at Federal, State or Municipal level, depending on the type of activity and the scale and localization of the project. The polluter-pays principle is expressed in the penalties, sanctions and requirements for reparations to which offenders are subject if they cause harm to the environment. Note that mining is an activity that admittedly implies damages to the environment; hence, the miner has the constitutional obligation to restore what has been degraded.

The environmental legislation, combined with the environmental principles of the Federal Constitution and of the Brazilian Civil Code ${ }^{8}$, establishes water as a public good for common use, describing it generally as an environmental resource, together with other elements of ecosystems. Environmental resources are for general use of the whole community, being essential to acquire and maintain a healthy quality of life and to reach the ideal ecological equilibrium. On the other hand, the private use of water resources through the permit system of the National Policy for Water Resources does not denote possession of the water itself [9], considering the premise of inalienability of public goods for common use [10]. Rather it implies the right to use water for economic or individual purposes, observing the restrictions imposed by law and by the collective interests. Integrating the public domain with other environmental resources, water in general cannot be privately or individually owned. Rather the opposite since the public bodies with legal competence for managing public goods are bound by law to guard them (include water) for the overall benefit of the community [10].

Against this background, groundwater acquires a strong environmental dimension. As an environmental resource, it constitutes as an important reserve of drinking water for future generations and must subject to protective and conservative policies for keeping an ecologically balanced environment. The economic use of groundwater resources promotes either private or collective interests, supporting economic activities or supplying the population with essential public services. Nevertheless, the economic dimension of groundwater must be compatible with the intergenerational obligation of guaranteeing groundwater reserves in adequate quality and quantity for the future.

\section{Mining and Mineral Waters-Regulatory Framework}

The Code of Mineral Waters (CMW) was enacted while the Constitution of 1937 and the former Code of Mines of 1940 were in force. The Constitution of 1937 reiterated most of the principles for mineral resources exploitation introduced in 1934. According to it, the property of mines and other subsoil wealth was considered distinct from the ownership of the land, and their economic exploitation relied upon federal grants. These main principles were later reinforced by the Federal Constitution of 1988, currently in force, which extends the Federative Union's domain over mineral resources even for those undiscovered, wherever they are settled (on surface or in the subsoil), and also defines that mining activity must be carried out in the national interest, following policies and rules for protection of the environment and for the recovery of degraded areas by the mining company.

The CMW was promulgated in 1945 after the work of a Hydrology Commission nominated by the Ministry of Agriculture in 1940. The law clarifies that the economic exploitation of mineral waters is governed by the legal regime for mineral resources based on the provisions of the Code of Mines of 1940, subsequently updated by the Code of Mining (CM) of 1967.

Since 1967, the CM has governed all aspects of the mining sector in Brazil ${ }^{9}$, from exploration of mineral resources to production and commerce of mineral commodities. Mineral rights are established and extinguished by successive administrative proceedings, mostly of a binding nature [11], issued by both the Ministry of Mines

\footnotetext{
${ }^{7}$ The construction, installation, expansion and operation of any potentially hazardous activity are subject to a three-step licensing process (preliminary, installation and operation licences). The preliminary, installation and operation licences of a project are time-limited, not exceeding five years, six years and ten years, respectively. The environmental licensing process eventually involves the realisation of public meetings for divulgation of the project to the affected community.

${ }^{8}$ Article 99 of Brazilian Civil Code (Law 10.046 of 10/01/2002).

${ }^{9} \mathrm{By}$ the time of drafting this article, 1967 Code of Mining was still in force. Nevertheless, the bill number 5.807/2013 has been in progress in the National Congress since 18/06/2013, which will update the cited law.
} 
and Energy (MME) and the National Department of Mineral Production (DNPM).

Authorization and concession are legal regimes defined by the CM that represent the two main phases of the mining activity, respectively the exploration and exploitation stages. The authorization regime comprises a time-limited title (2 to 3 years, renewable) that allows either individuals or companies to conduct, at their own expense, all prospecting works needed for the definition of an ore deposit, evaluation of mineral reserves and grades, as well as the determination of their economic feasibility. The concession title is issued by the MME, has unlimited duration and allows private companies to carry out mining operation projects that have been previously submitted to an environmental licensing process.

The Constitution empowers the Federative Union to dispose of mineral wealth, be it on the surface or underground, without any legal restriction. The first competent applicant to request a survey grant for a particular available area can obtain exploration priority rights. The right of priority, also known as the "first come, first served" rule, is one of the mining activity principles that guarantees democratic access to mineral resources, as the Union must grant mineral rights to whoever first legitimately applies for it.

The mining sector has a peculiar dynamic as economic activity. Despite the public nature of mineral resources, mining is not a public service. All investments (normally of a long term nature) and usually high risks are at the expense of private parties. Once a mining title has been issued, the miner begins to have a right/duty to exploit mineral deposit until its depletion. The property of the mined product is guaranteed to him, as is the right to use, enjoy, sell or rent the mine and to use the mineral rights as collateral. Thus, the exploitation concession is the administrative act that allows the shift of the ownership of a public asset (in situ ore deposit) from the Union to private hands (mined ore deposit), incorporating it into their assets [12] [13].

Mining is constrained by the immovable nature of the ore deposits. Mineral resources can be found anywhere, outcropping the surface or deep inside the soil. Considering the random and unpredictable natural occurrence of mineral resources, mining is considered to be of public utility or of social interest and direct exploitation in some protected areas can be allowed only under specific environmental law provisions ${ }^{10}$.

\section{The Code of Mineral Waters (CMW)}

Mineral water is legally defined as groundwater with a distinct chemical composition or physical-chemical properties which confer a medicinal action. The CMW recognizes two categories of groundwater: mineral waters and potable table water. Both categories of groundwater are considered mineral substances and are governed by the mining legal framework. The CMW regulates two only possible end uses, for bottling process and for spas purposes.

Mineral waters are defined as having a medicinal action depending on their composition. They are characterized by a wide range and defined amounts of some chemical compounds (radium, sodium and calcium bicarbonate, sulphate, sulphur, nitrate, sodium chloride and iron), by the presence of dissolved gases (carbon dioxide, hydrogen sulphide, and short half-life radioactive gases) and by the contents of noteworthy trace elements (iodine, arsenic, lithium, etc.). Together with chemical composition, some properties of the water at the source, such as temperature and temporary radioactivity, are also used to classify a mineral water source.

Potable table water, on the other hand, has nothing special at all, i.e. comprises groundwater which does not reach the chemical or physical parameters defined by the CMW, but only potability. Potable table water theoretically is not associated with any sort of presumable beneficial health effect, but is suitable for bottling purposes.

According to the CMW, water with particular chemical and physical parameters is defined as having therapeutic benefits, even though no therapeutic effects may have been shown empirically by medical experts. The medicinal action is the main legal criterion that defines a mineral water, but the procedure of testing for any favorable effect on health is not a legal requirement ${ }^{11}$, because the law sets down the chemical and physical parameters for mineral waters (Art. 35 and Art. 36 of CMW).

The CMW was enacted at a time when several spas and hydromineral resorts were designated as important healing centres in Brazil. Mineral waters were normally known as "mineral-medicinal” or "thermal-medicinal"

\footnotetext{
${ }^{10}$ Resolution 369/2006 of the National Environmental Council (CONAMA) reinforces the public utility and the social interest of activities of exploration and extraction of mineral substances, by permitting eventual intervention or removal of wood cover in Permanent Protected Areas defined in the Brazilian Forest Code.

${ }^{11}$ Groundwater classified as "oligomineral”, "nitrated” and "chlorided” are kinds of mineral water that exceptionally must have its beneficial effect on health attested through empirical measurements carried out by specialized doctors, which results depending on approval of a board of experts in Crenotherapy. CMW, Art. 35, I together with Art. 1, §2 and §3.
} 
waters, because Crenotherapy was experiencing great popularity as a traditional practice in medicine [5] [14]. After the Second World War, however, the discovery of penicillin and the spread of the pharmaceutical industry have been identified as the main reason for the decline of those medicinal practices, not only in Brazil but also worldwide [15]. Bottled mineral waters have their origin in the spas and resorts, retaining a connexion to their sources and the brands that carried the prestige of some known effects on health, but slowly they became more and more separated and diverged from the resorts [15], splitting up completely and developing as independent companies in a fast growing sector. The production of bottled mineral water before 1970s were lower than 100 million litres/year, increasing to around 800 million litres/year in 1990 and then boosting to more than 3000 million litres/year from 2000 forward [16]. By the end of the 1950s, bottled mineral water was no longer sold in pharmacies but had begun to be marketed in supermarkets, restaurants and bars [15], and was seen not anymore as a medicine, but also as a domestic consumer good. The mineral water sector changed its focus from healing purposes, leaving the medical scope and approaching the bottled beverage industry, to dealing with the primary purpose of the water: thirst quenching.

Considering the extinction of the Crenotherapy specialty or subspecialty in medicine, the confirmation of some therapeutic use of a mineral water has not been made since the 1960s. In that way, the classification of mineral water has been based only on the chemical or physical properties defined by law. On the other hand, the legally defined parameters used to classify a mineral water cover such a wide range (for example the temperature in the source) that practically any grade of mineralization or even waters containing low amounts of trace elements (for example fluoride) are enough to categorize them as mineral water. In practice, today, any naturally potable groundwater is likely to be classified either as mineral water or as potable table water [15] [17] if suitable for bottling or for spa purposes.

\section{Mineral Waters versus Minerals-A Comparison}

Mineral water seems an alien mineral substance within the mining sector and remarkable differences between mineral water and other minerals can be pointed out as follows: 1 ) mineral water is neither a mineral nor a fossil substance; 2) mineral water is a renewable resource, in theory; 3) mineral water is produced directly for human consumption, and because of that, the sector must follow standards and rules promoted by health, sanitation and environmental institutions; 4) inspection procedures for mineral water are more similar to the ones taking place in the sanitation and health sectors than in the mining one; 5) exploitation of mineral water implies a minimal alteration of the surface and minimized visual impacts at the point of extraction (punctual extraction); 6) mineral water exploitation is conservative because it involves a delimitation of a protection area around the source with restriction to any underground work or intervention; and 7) mineral water extraction and processing cause desirable minimal change in the original water composition.

The first basic difference between minerals and mineral waters refers to their nature. Water is not considered a mineral because it is liquid and does not show a crystalline structure [18]. Mineral water is not the only exception within other mineral substances though. For example, mercury occurs as a liquid and opal is amorphous, so both are considered mineral-like substances, named mineraloid, but are not formally accepted as minerals. Some chemical compounds induced by biological processes, such as marine phosphorites, are not truly minerals either. In fact, being a mineral is not a sine qua non for being regarded as a mineral resource.

Another key difference regards renewability. Mineral water is a drinkable groundwater which, theoretically, is a renewable resource connected directly or indirectly to surface waters, taking part in the hydrological cycle. According to Rebouças, 97\% of all groundwater is meteoric in origin and was recharged by infiltration of surface water into the ground at some moment in geological time [19]. The concept of renewability for groundwater, however, is relative to time and can be divided into renewable and non-renewable. Renewable aquifers receive natural recharge and have the ability to replenish their reserves depending on the level of connectivity with surface waters, in a period of time comparable to a human lifespan. On the other hand, aquifers that need a very long period (hundreds to thousands of years) to replenish their stocks are known as non-renewable or fossil [20]. Non-renewable groundwater is normally found in unconfined aquifers where contemporary recharge amounts are small or infrequent due to severe climatic conditions, as well as in confined sections of some aquifers where active recharge is negligible [20] [21]. "Groundwater mining” is the convenient term often used for groundwater developments that involve the abstraction from fossil or non-renewable water reservoirs. In other words, groundwater mining may be defined as the exploitation of groundwater at a rate that is much greater than the rate of 
replenishment of the aquifer storage [22] [23].

Nevertheless, the principles that underpin the mining activity and water resource management are quite different. One of the problems of mineral water management is the premise that mineral resources can be exploited until ores deposits are exhausted, because this principle implies some environmental concerns related to the protection and conservation of groundwater as an environmental resource, which are not properly covered by the CMW or the CM. Because the CMW and the CM antedate the Brazilian environmental legislation, most of the policies and rules concerning environmental protection affect the mining sector directly without disrupting the mining legal framework. The environmental legislation introduced another step for the mining activity, by submitting mining developments to environmental licensing process regarding its installation and operation. Considering that mining is legally recognized as a potentially hazardous activity to the environment, mineral exploitation (including mineral water) is not authorized unless previous environmental impact assessment, or another similar instrument, has been carried out. The theoretical depletion of a mineral water "deposit" can be legally authorized $^{12}$, but this is unlikely to happen because the exploitation would not be licensed by the environmental authority in the first place.

The second problem in considering mineral water as a mineral resource refers to the ownership transference of a public asset to a private party. Legally, the miner owns the mined product as part of his private assets. This means that the abstracted mineral water belongs to the miner, differently than users of water resources. As seen before, according to Brazilian Water Law's principles, water rights refer to the private use of a public good with the public good remaining in public hands. Then the mining principle conflicts directly with the constitutional assumption that water is a public good for common use by the people and is inalienable. Under Brazilian Administrative Law, public assets for common use are not susceptible to being ascribed to individual ownership, since they belong to everyone and the government is in charge of managing them for the benefit of the society [9]. From an economic perspective, the exclusive use of a water resource by a private party depends on an administrative permit act as stated by a national and regional set of policies and rules. The management of mineral water under the mining exploitation regime seems, therefore, to be incompatible with the premise of the inalienability of water.

Finally, some inconsistency between the CM and the CMW rests on the principle of management of mineral water for end use. Mineral water is managed exclusively for bottling process or for spa purposes. Any other use (for example, water supply or irrigation) is not regulated by the CMW and is out of the federal jurisdiction of DNPM. Mining activity, however, is deeply dependent on the fixed location of ore deposits and on its non-renewability rather than on the end uses of extracted mineral substances.

\section{Conflicts between Mineral and Groundwater Sectors}

Mineral water management can potentially conflict with other sectors, such as health and sanitation, environmental protection, land use planning, and groundwater resource management [24]. Regarding the health sector, there are concurrent administrative levels of the government, such as the Ministry of Health and the Ministry of Mines and Energy, which enact conflicting norms. This is the case for sanitation inspection procedures for mineral water industries and labelling of bottled mineral water ${ }^{13}$. Another source of conflict lies in the necessary intervention in preserved wooded areas (named Permanent Protection Areas defined in the Brazilian Forest Code) to construct the source protection building around mineral water springs, that would be theoretically authorized only under special circumstances defined by law ${ }^{14}$. While environmental law states that Permanent Protected Areas must be preserved, the mineral water law determines deforestation can be carried out in localized portions of those protected wooded areas [24], which can result in fines by the environmental body.

\footnotetext{
${ }^{12}$ The concept of groundwater reservoir depletion is somewhat distinct from mineral ore deposit depletion. Depletion of groundwater storage does not mean the complete drainage of the aquifer because is rather unlikely to happen, since an important part of an aquifer is renewable and the stocks can be replenished by recharge. Nevertheless, the continuing abstraction of non-renewable aquifers represents, in fact, reduction in groundwater reserves, triggering several negative side effects. According to Llamas \& Custodio, the common undesirable side effects of intensive abstraction of groundwater are the drawdown of the hydraulic head locally and regionally, alteration in the river-aquifer relations (drying up of springs and reduction of river-base flow), alteration in the groundwater quality (normally degradation) and land collapse [23].

${ }^{13}$ Ordinance 470/1999 of the Ministry of Mines and Energy conflicts with Resolution RDC 259/2002 of the National Sanitary Surveillance Agency about labelling of bottled products. Likewise, Ordinance 374/2009 of the DNPM conflicts with Ordinance 326/1997 of the Ministry of Health regarding sanitary standards for bottling industries [24].

${ }^{14}$ See Note 10 .
} 
Nevertheless, the mineral water sector collides directly and more frequently with groundwater sector. Official statistics demonstrate that almost 190,000 permits for water use had been granted by July 2011, representing a total authorized yield of $6800 \mathrm{~m}^{3} / \mathrm{s}$, where groundwater still represents a minor part, of about 8400 permits and a total yield of $520 \mathrm{~m}^{3} / \mathrm{s}$ (or 1,872,000 $\mathrm{m}^{3} / \mathrm{h}$ ) [25]. Compared with the official statistics for the water resource management sector, the production of mineral water represents a minimal, if not negligible, proportion of the end use of groundwater in Brazil, which is estimated at 1024 exploitation concessions granted by the end of 2011, representing a total yield of $0.28 \mathrm{~m}^{3} / \mathrm{s}$ (or $1023 \mathrm{~m}^{3} / \mathrm{h}$ ) [26]. Although there is such a quantity difference, the potential conflicts between the groundwater and mineral water use still occur, but are rather a localized issue, especially in certain regions where mineral and thermal waters play an important role in production of bottled beverages or for spa tourism.

A well-reported case of conflict takes place in the Caldas Novas region, in the central part of Brazil, an important tourist destination in Goias State, where the presence of thermal water sources has been attracting tourists from all over the country for leisure tourism and balneotherapy since the 1960s. A large number of wells (more than 400 wells) had been drilled and groundwater abstraction was almost uncontrolled, resulting in a drastic decrease in the regional water level of the thermal aquifer, with a decrease of more than $50 \mathrm{~m}$ from its original level [27]. From 1996, the National Department of Mineral Production (DNPM) has been adopting a set of control measures for the thermal aquifer in the Caldas Novas region, aiming to recover of its falling potentiometric surface and to maintain the thermal characteristics of the aquifer that was about to be depleted because of groundwater overexploitation [27]. The set of procedures comprised the interdiction of 180 illegal wells, the prohibition of use of thermal water from 155 wells for domestic purposes, the restraint and regular monitoring of the production yield in the 89 authorized thermal water wells and the suspension of granting of new mineral rights in the region ${ }^{15}$. Recently, the control measures successfully led the aquifer to recover about $30 \mathrm{~m}$ above the lowest water level registered in the region in the middle 1990s, but some concerns still remain because monitoring data have shown a progressive tendency for thermal aquifer drawdown that has not adequately been addressed $^{16}$. On the other hand, the supremacy of thermal groundwater use for mineral water spas has also conflicted directly with the local public water supply service, because the municipality had their thermal water wells restricted by the federal regulatory body, which ultimately led the matter to be brought before a court of justice to be settled ${ }^{17}$. Only 30 shallow wells are authorized by the State body for abstraction of cold groundwater for domestic uses inside the restricted area [27].

Another reported case of conflict refers to the Nestlé industry in São Lourenço city, a traditional hydromineral resort in Southeast Brazil. The local population organised protests from 1999 to 2004 against the multinational company, which was suspected of overexploiting the aquifer by intensive pumping of wells for bottled water production [28]. Protests focused on the distrust of the multinational company being granted with mining rights to exploit mineralized groundwater from wells enclosed in a resort with reputed medicinal springs. The supposedly high rate of groundwater pumping for bottling purposes would have caused the falling water level of the aquifer, with apparent changes in water composition and the drying of some secular springs. The Nestlé industry was involved in a trial, with great negative repercussions shown both in national and international media. In the end, some irregularities were found in the industry's operation, but there was no direct evidence of aquifer overexploitation due to the production of bottled water. Nestlé had their activities adjusted to the Public Ministry's requirements by signing an agreement in 2006 that restricted one of the pumping wells, and also limited its total production to 13 million litres of mineral water per year [28].

Aware of the conflicts of jurisdiction between the federal regulatory body (management of mineral water) and State institutions (management of water resources), the National Water Resource Council (CNRH) in 2002 started a long discussion on this issue, conducted within its Groundwater Technical Chamber (CTAS). The discussion about the integration between the management of mineral water and groundwater were particularly lively in 2004, when a seminar was held focusing conceptual and legal issues in each sector. The discussion was

\footnotetext{
${ }^{15}$ DNPM Ordinance 52/1999 defined an area of restriction of 107.3 hectares in the Caldas Novas and Rio Quente regions in which 89 mineral water wells have their yields monitored monthly, with a maximum total yield of $1800 \mathrm{~m}^{3} /$ hour, at a pumping rate of 14 hours/day.

${ }^{16}$ The drawdown tendency of the Araxá Thermal Aquifer System, in Caldas Novas region, can possibly be related to some interference between the thermal water wells authorized by the DNPM and the municipal wells producing groundwater for the public water supply [28].

${ }^{17}$ According to Andrade \& Almeida, the Caldas Novas' municipal water supply service agreed to replace the volume of groundwater abstracted from the Araxá Thermal Aquifer System for surface water catchment work carried out in Pirapitinga River. As the work was finished at the end of 1996, the six municipal wells were restricted by the DNPM in 1997. Restrictions of the abstraction of groundwater were later released, from 2008 until the end of 2011 by a judicial sentence, using the justification that the use of surface water by the municipal water service did not adequately supply the local population [28].
} 
somewhat heated and opinions were clearly polarized into two divergent points of view: on the one side representatives of the National Department of Mineral Production (DNPM) and of the National Confederation of Industry were against any attempt to integrate mineral water developments with the permit system of the National System of Water Resource Management (SINGREH). On the other side, representatives of Federal and State bodies for the environment and water resource management argued the opposite [16] [29] [30]. In the end, the Council published Resolution 76/2007 focusing mainly on guidelines to promote the dialogue between federal and states administrative institutions, as well as the sharing of technical information of each permit system. This resolution seeks, to stimulate the "integration and coordinated action" of the organisations involved (federal and state agencies) without formally stating that SINGREH should be an additional management instrument for mineral water developments ${ }^{18}$.

A likely reason for this sort of conflict is that mineral water today is not so far distinct from "ordinary" groundwater. According to Queiroz, 88\% of all mineral water sources in Brazil produce very lightly to lightly mineralized water, showing a total concentration of dissolved chemical compounds no higher than $300 \mathrm{mg} / \mathrm{L}$ [31]. About $10 \%$ of the sources are classified as potable table water and $27 \%$ of the sources are classified as mineral water exclusively due to insignificant amounts of fluoride as a noteworthy component [31]. This study also shows that $43 \%$ of all Brazilian mineral water sources are characterized exclusively by intermittent physical and chemical parameters, such as temperature and/or temporary radioactivity, which means they are truly mineral waters only at, or near to, their sources. Away from their sources, they are only potable table waters (or common potable groundwater) because their temperature has changed and their dissolved gases have been lost at the time they are available for consumption. While those intermittent physical-chemical characteristics are significant for spa purposes, they are irrelevant for the consumer of bottled mineral water.

Only a small part of all mineral water sources in Brazil, about 20\%, is characterized by greater diversity of chemical compounds and/or high temperature and/or natural carbonation, characteristics that are strictly in accordance with the legal chemical limits established in Article 35 of the CMW and with the legally stated definition of a supposed medicinal action for mineral water. This percentage is roughly the proportion of mineral water sources $(14 \%)$ that historically were devoted to some medicinal purpose or aimed at leisure tourism in spas and hydromineral resorts [31].

Considering only bottled mineral water, one third are very lightly mineralized (total dissolved solids $<50$ $\mathrm{mg} / \mathrm{L}$ ), associated with fast water circulation through shallow aquifers ( $\mathrm{pH}<6$, acidic), theoretically highly vulnerable to surface-driven contamination, and furthermore one quarter of the sources shows some signs of anthropic impact indicated by the presence of nitrate ${ }^{19}$, even though they are potable [32]. There are some sources in the North and Northeast of Brazil that produce mineral water compositionally similar to rainwater, as they show total dissolved solid contents below $5 \mathrm{mg} / \mathrm{L}$ and pH between 4 and 5 [17] [32].

In fact, the CMW currently fails to sort out conflicts between the water and mining sectors because the law does not provide reasonable well-defined limits, based on intrinsic parameters, which can without doubt differentiate mineral water, potable table water and common groundwater. With some exceptions, in practice, they are almost the same, because the CMW allows a loose interpretation of the legal parameters used to classify any potable groundwater either as mineral water or as potable table water.

In the 1940s, when the CMW was drafted, there was no stated policy at federal level to deal with other economic uses of groundwater apart those regulated by the CMW. Furthermore, the limited knowledge in Hydrogeology in the 1940s and the lack of technology in underground works have possibly led to the misconception that mineralized groundwater was disconnected from surface waters, causing mineral water management to be regulated more closely to the mining sector, completely separated from surface water resource management [15]. The CMW's provisions worked without major conflicts for years, until the Federal Constitution came into force in 1988, which introduced an environmental dimension for water, previewed a national-level integrated water resource management, and empowered the States with jurisdiction over groundwater.

With groundwater being defined by the Constitution as a natural resource under States' jurisdiction, there is a risk that potable table water would in fact be interpreted as being "common" groundwater, since they are tech-

\footnotetext{
${ }^{18}$ Although there was no consensus in the CNRH, Serra observes that some states actually provided legal means for the integration of mineral water claims into the SINGREH permit system (states of Bahia, Paraná, Pernambuco and Rio Grande do Norte). This occurs because States have legislative authority to enact administrative laws regarding environmental protection and water use permits, which vary from State to State [15].

${ }^{19}$ Bertolo et al. argue that groundwater with nitrate concentration above $3 \mathrm{mg} / \mathrm{L}$ has been somewhat impacted by surface derived anthropic contamination [32].
} 
nically the same. If this were the case, the CMW's provisions designating potable table water as a mineral resource would conflict directly with the 1988 Federal Constitution. Accordingly, neither potable table water nor mineral waters would be regarded as assets belonging to the Union, because the Federal Constitution makes no distinction between different types of water, but includes all groundwater under the States' domain. As vehemently argued by Serra, if no exception is made for groundwater, the CMW as a whole would be implicitly revoked by the 1988 Federal Constitution and mineral water would fall under States' competence as a water resource [15]. This is a controversial point of view, however, and is not shared by the Ministry of Mines and Energy's advisory board of Federal Attorneys (Advogado Geral da União). They argue that the CMW is in accordance with the Federal Constitution, because mineralized groundwater is solidly defined as a mineral resource at infra-constitutional level [29].

\section{The Need for Updating the Brazilian Legislation for Mineral Water}

The concepts used by the CMW for defining mineral water lie in the sparse scientific and medical knowledge about the therapeutic uses of mineralized, radioactive and thermal waters that was available in the 1940s. Some properties of the water that are directly linked to the source, such as high temperature and dissolved gas content, are relevant for therapeutic purposes and have been extensively reported as beneficial to health in both recent and older international literature on spa therapy [33]-[35]. Some therapeutic effects of mineral waters, however, are currently asserted in law, but are unsubstantiated by science. The actions of chemicals are now much better understood than they were when the law was drafted, and it is now clear that the law defining the therapeutic benefits of some of the chemical compounds found in mineral water seems to be misleading.

For example, nitrate and arsenic are defined by the CMW as likely to be associated with some medicinal action, but they in fact have been found to have some harmful effects in humans, so that their concentration in drinking water is now determined by rigid standards ${ }^{20}$. On the other hand, the presence of radioactivity (permanent or temporary) in water, which for a long time Crenotherapy had credit with the mild therapeutic effects of lightly mineralized water [36], has had its beneficial action on health questioned, and it has even been described as hazardous to humans [17] [37]. If there are controversies about the benefits or possible harms to humans related to certain components in drinking water, precautionary concerns should be taken into account in using these parameters for mineral water classification and its use for human consumption.

The concept of mineral water carrying some medicinal effect is currently in disuse in Brazil, mainly because medicinal practices using mineral and thermal waters are virtually extinct due to the lack of experts in Crenotherapy [14] [15]. As the linkage between medicinal therapy and mineral water has been lost, the principles that underpin the Brazilian legal framework for dealing with mineralized groundwater should be revised. As pointed out by the reputed Brazilian jurist, Miguel Reale, "the legal rule must be formally valid and socially effective" [38]. In other words, the effectiveness of the law is dictated by its engagement with the social experience, to the point that "the disuse [of a law] can occur because the legal rule has never been applied or, at a certain time, has ceased to be applied, since the obedience to a diverse customary norm started to prevail within the community, with the oblivion of the legal rule" [38]. The same author also argues that: "the public authorities have a duty to avoid the divorce between social reality and certain legal rules, which are not, or never have been effective, because it [the law] is in conflict with trends and authentic dominant interests within the community” [39].

The current political climate in Brazil is particularly favorable to making public authorities aware of the urgent need for reopening the discussion for updating mineral water legislation, because the government has been making efforts to modernize outdated laws. In this direction, the federal government has released the bill that will replace the 1967 Code of Mining and will improve the institutional and legal framework of the mining activity in Brazil. The bill number 5.807/2013 is before the National Congress since June of 2012 and several changes in principles and management instruments for dealing with mineral resources are likely to happen by the end of 2014. The expected changes, however, will not affect the current management style of mineral waters.

A desirable scenario would be for the government to open a public consultation process followed by a transparent discussion through public meetings, involving different sectors of society with competing interests in the mineral water issue, such as the mining, groundwater, health and food sectors. Academic knowledge and the experience of other countries would be of great value in supporting the discussion and the law-making process.

\footnotetext{
${ }^{20}$ According to Resolution 274/2005 of the National Health Surveillance Agency, the maximum amount of dissolved nitrate and arsenic in drinking water is, respectively, $50 \mathrm{mg} / \mathrm{L}$ and $0.01 \mathrm{mg} / \mathrm{L}$.
} 
The government should provide an open-minded debate for answering the big question: which is the model for mineral water management that society really wants and should pursue? The multidisciplinary debate should lead to answers regarding the establishment of (new) principles and concepts for mineral water, the definition of the management instrument, a decision about the legal regime of exploitation and the determination of well-defined technical parameters that unquestionably differentiate mineral water from normal groundwater.

The current design of the mineral water sector has evolved so that most of the mineral water sources today are barely distinguishable from normal groundwater. The connection between mineral water and medicine has been lost for a long time and so is the linkage with the principles that underpin the mining legal framework. Keeping mineral water management in the mining sector can only be justified if the principles governing mineral water legislation are in accordance with the non-renewability of aquifers and with the fixed location of the mineral water sources ${ }^{21}$. Otherwise, mineral water will continue to be treated like an alien substance with an alien model of management within the mining sector.

Nevertheless, keeping mineral water management in the mining sector does not sort out concerns about the compatibility of the mining legal regime for mineral water exploitation, because the mining alienability principle conflicts directly with the environmental dimension of groundwater.

\section{Conclusions}

For reasons that have little to do with hydrogeology, but much to do with currently disused traditional spa practices, mineral water in Brazil is considered to be a mineral substance and even today it is treated differently to water resources. The CMW is a curious case in which the law did promote a change in the nature of a natural resource, namely, groundwater. The legal ascription of mineral water as a mineral substance should never exclude its natural condition as a groundwater resource. In fact, it is almost physically impossible to separate mineralized groundwater from "ordinary" groundwater because they are interconnected in an aquifer, taking part of a dynamic system composed of flowing water and rock. Furthermore, mineral water has now acquired a water resource status in its own right, taking into account how legal instruments for water management have evolved in Brazil in the last decade.

The cases of conflict reported in this article highlight the inversion of priorities stated by the Constitution, which was supposed to have the supremacy of public over private interests. In the Central Brazil conflict case, spa tourism is favoured in the end use of mineralized water for private interests rather than for the public water supply service. The regime of mineral water production under the mining legal framework sometimes denies some principles and guidelines of environmental and water resource legislations that should not happen today.

There will be inevitable conflicts of jurisdiction on mineralized groundwater while the CMW remains in force, because it is founded on outdated definitions and disused concepts regarding water intrinsic parameters and end uses. The CMW has ceased to be effective and barely reflects the current design of the mineral water market, since it has been drafted since the 1960s primarily for the production of bottled beverages rather than for medicinal purposes. Bottled mineral water today favours characteristics agreeable to consumer tastes (lightly mineralized bottled water), with the oblivion or the principles originally stated by law (mineral water as a remedy). More than $80 \%$ of mineral water sources in Brazil are currently devoted to production of bottled water. For the consumers of bottled mineral water, the only thing that really matters is the quality of groundwater for drinking and not its presumable medicinal effects on humans.

There is an urgent need to reopen the discussion aimed at a possible revision of the CMW. This piece of legislation has been frozen in time and does not adequately take into account the deep changes in the way society has been dealing with water, in general, and with the environment, in particular. For the discussion process, some aspects should be taken into account, such as serious concerns about the compatibility of the CMW's principles with the environmental dimension of groundwater. The ascription of mineral water as a mineral substance belonging to the Union's assets and the adoption of the legal regime of mining are frankly in disagreement with the constitutional premises of groundwater under the States' jurisdiction and with the inalienability of water as a public good for common use.

\section{Acknowledgements}

The first author thanks the DNPM for supporting this research and also the CNPq (Brazilian Council of Tech-

\footnotetext{
${ }^{21}$ That would be the case of mineralized groundwater from fossil aquifers, for example.
} 
nological and Scientific Development) for the post-doctoral scholarship provided during 2012-2013 period.

\section{References}

[1] Porto, M. and Kelman, J. (2000) Water Resources Policy in Brazil. Rivers-Studies in the Science Environmental Policy and Law of Instream Flow, 7, 250-259. http://www.kelman.com.br/pdf/Water_Resources_Policy_In_Brazil_2.pdf

[2] Benjamin, A.H., Marques, C.L. and Tinker, C. (2005) The Water Giant Awakes: An Overview of Water Law in Brazil. Texas Law Review, 83, 2185-2244.

[3] ANA, Brazilian National Water Agency (2007) GEO Brazil Tematic Series, Water Resources Component of a Series of Reports on the Status and Prospects for the Environment in Brazil. ANA/PNUMA, Brasília. http://arquivos.ana.gov.br/institucional/sge/CEDOC/Catalogo/2010/GEOBrasilResumoExecutivo Ingles.pdf

[4] Hirata, R., Zoby, J.L.G. and Oliveira, F.R. (2010) Groundwater: Strategic or Emergency Reserve. In: Bicudo, C.E., Tundisi, J.G. and Scheuenstuhl, M.C.B., Org., Waters of Brazil: Strategic Analysis, Instituto de Botânica, São Paulo, 149-161. (In Portuguese) http://www.ianas.org/books/aguas_do_brasil_Final_02_opt.pdf

[5] ANA, Brazilian National Water Agency (2011) Permit System for Water Resources Use. ANA, Brasília. (Cadernos de Capacitação em Recursos Hídricos, Vol. 6) (In Portuguese)

http://arquivos.ana.gov.br/institucional/sge/CEDOC/Catalogo/2012/OutorgaDeDireitoDeUsoDeRecursosHidricos.pdf

[6] Drummond, J. and Barros-Platiau, A.F. (2006) Brazilian Environmental Laws and Policies, 1934-2002: A Critical Overview. Law \& Policy, 28, 83-108. http://dx.doi.org/10.1111/j.1467-9930.2005.00218.x

[7] Daibert, A. (2009) Historical Views on Environment and Environmental Law in Brazil. The George Washington International Law Review, 40, 779-840.

[8] McAllister, L.K. (2008) Revisiting a "Promising Institution”: Public Law Litigation in the Civil Law World. Georgia StateUniversity Law Review, 24, 693-734.

[9] Pompeu, C.T. (2010) Water Rights in Brazil. 2nd Edition, Editora Revista dos Tribunais, São Paulo. (In Portuguese)

[10] Di Pietro, M.S.Z. (2010) Private Use of a Public Good by a Private Party. 2nd Rdition, Editora Atlas S/A, São Paulo. (In Portuguese)

[11] Freire, W. (2010) Fundamentals of Mining Law. Jurídica Editora, Belo Horizonte.

[12] Trindade, A.D.C. (2009) Mining Law Principles. In: Souza, M.M.G., Coord., Mining Law in Evolution, Editora Mandamentos, Belo Horizonte, 47-76. (In Portuguese)

[13] Trindade, A.D.C. (2011) Perspectives for a Mining Law Reform. In: Martins, J., Lima, P.C.R., Queiroz Filho, A.P., Schüller, L.C. and Pontes, R.C.M., Coord., Mineral Sector: On Route to the New Legal Framework, Câmara dos Deputados, Brasília, Série Cadernos de Altos Estudos 8, 205-220. (In Portuguese)

http://www2.camara.leg.br/a-camara/altosestudos/arquivos/setor-mineral-rumo-a-um-novo-marco-legal/setor-mineral-r umo-a-um-novo-marco-legal

[14] Quintela, M.M. (2004) Thermal Knowledge and Practices: A Compared Perspective in Portugal (São Pedro do Sul Thermal Spa) and in Brazil (Caldas da Imperatriz Hot Springs). História, Ciências, Saúde, 11, 239-260. (In Portuguese) http://www.scielo.br/scielo.php?script=sci pdf\&pid=S0104-59702004000400012\&lng=en\&nrm=iso\&tlng=pt

[15] Serra, S.H. (2009) Mineral Waters of Brazil. Millennium Editora, Campinas. (In Portuguese)

[16] Caetano, L.C. (2005) Mineral Water Policy: An Integrated Proposal for the Rio de Janeiro State. Ph.D. Thesis, State University of Campinas, Campinas. (In Portuguese)

[17] Bertolo, R.A. (2006) Reflections on the Mineral Water Classification and Chemical Characteristics of Bottled Mineral Water in Brazil. Proceedings of the 14th Brazilian Groundwater Congress, Curitiba, 7-18 November. (Revista Águas Subterrâneas, Supplementary Issue) (In Portuguese) http://aguassubterraneas.abas.org/asubterraneas/article/view/23114/15229

[18] Nickel, E.H. (1995) The Definition of a Mineral. The Canadian Mineralogist, 33, 689-690.

[19] Rebouças, A.C. (2006) Groudwaters. In: Rebouças, A.C., Braga, B. and Tundisi, J.G., Org., Freshwaters in Brazil, 3rd Edition, Editora Escrituras, São Paulo, 111-144. (In Portuguese)

[20] Margat, J., Foster, S. and Droubi, A. (2006) Concept and Importance of Non-Renewable Resources. In: Foster, S. and Louks, D.P., Eds., Non-Renewable Groundwater Resources, A Guidebook on Socially-Sustainable Management for Water-Policy Makers, UNESCO, IHP-VI, Series on Groundwater 10, 13-24. (IHP/2006/GW-10) http://unesdoc.unesco.org/images/0014/001469/146997e.pdf

[21] Foster, S., Nanni, M., Kemper, K., Garduño, H. and Tuinhof, A. (2005) Utilization of Non-Renewable Groundwater: A Socially-Sustainable Approach to Resource Management. The World Bank, Washington DC. (GWMTE Briefing Note Series, Note 11). 
http://documents.worldbank.org/curated/en/2003/01/5161421/utilization-non-renewable-groundwater-socially-sustaina ble-approach-resource-management

[22] Custodio, E. (2002) Aquifer Overexploitation: What Does It Mean? Hydrogeology Journal, 10, 254-277. http://dx.doi.org/10.1007/s10040-002-0188-6

[23] Llamas, M.R. and Custodio, E. (2003) Intensive Use of Groundwater: A New Situation Which Demands Proactive Action. In: Llamas, M.R. and Custodio, E., Ed., Intensive Use of Groundwater, Challenges and Opportunities, A. A. Balkema Publishers, Lisse, 13-34.

[24] Caetano, L.C., Pereira, S.Y. and Dourado, F. (2012) Conflicts of Mineral Water Management in Brazil—Study Case: Rio de Janeiro State. Holos Environment, 12, 132-146. (In Portuguese) http://www.periodicos.rc.biblioteca.unesp.br/index.php/holos/article/view/2080/4935

[25] ANA, Brazilian National Water Agency (2012) Water Resources Conjuncture in Brazil. 2012 Report. ANA, Brasília. (In Portuguese) http://arquivos.ana.gov.br/imprensa/arquivos/Conjuntura2012.pdf

[26] DNPM, National Department of Mineral Production (2012) 2012 Mineral Summary. DNPM, Brasília, Vol. 32, 3-4. (In Portuguese) https://sistemas.dnpm.gov.br/publicacao/mostra_imagem.asp?IDBancoArquivoArquivo=7368

[27] Andrade, A.M.A. and Almeida, L. (2012) Potenciometric Level Performance of the Thermal Caldas Novas Aquifer Goias State and Control Measures Imposed by the National Department of Mineral Production (DNPM). Águas Subterrâneas, 26, 99-112. (In Portuguese) http://aguassubterraneas.abas.org/asubterraneas/article/view/25048/17678

[28] Guimarães, B.C. (2009) Environmental Collective Law and the (un)Sustainable Exploitation of Mineral Waters. Mandamentos, Belo Horizonte. (In Portuguese)

[29] Scalon, M.G.B. (2011) Mineral Waters and Water Resources: A Perspective of Integrated Management. Revista de Direito, Estado e Recursos Minerais, 1, 131-160. (In Portuguese) http://seer.bce.unb.br/index.php/rdern/article/view/5173

[30] Reis, A.M. (2005) Searching for an Integrated Management of Mineral Waters in Brazilian Legislation. In: Freitas, W.P., Ed., Environmental Law in Evolution, Vol. 4, Editora Juruá, Curitiba, 15-39. (In Portuguese)

[31] Queiroz, E.T. (2004) Mineral Waters of Brazil: Distribution, Classification and Economic Importance. DNPM, Brasília. (In Portuguese) http://www.dnpm.gov.br/mostra_arquivo.asp?IDBancoArquivoArquivo=377

[32] Bertolo, R., Hirata, R. and Fernandes, A. (2007) Hydrogeochemistry of Bottled Mineral Waters in Brazil. Revista Brasileira de Geociências, 37, 515-529. (In Portuguese) http://rbg.sbgeo.org.br/index.php/rbg/article/view/A-1647/984

[33] Lopes, R.S. (1956) Mineral Waters of Brazil, Value and Therapeutic Uses. Ministério da Agricultura, Rio de Janeiro. (In Portuguese)

[34] Mourão, B.M. (1992) Hydrological Medicine-Modern Therapy of Mineral Waters and Healing Centres. Secretaria Municipal de Educação, Poços de Caldas. (In Portuguese)

[35] Bender, T., Karagülle, Z., Bálint, G.P., Gutenbrunner, C., Bálint, P.V. and Sukenik, S. (2005) Hydrotherapy, Balneotherapy, and Spa Treatment in Pain Management. Rheumatology International, 25, 220-224. http://dx.doi.org/10.1007/s00296-004-0487-4

[36] Nasermoaddeli, A. and Kagamimori, S. (2005) Balneotherapy in Medicine: A Review. Environmental Health and Preventive Medicine, 10, 171-179. http://dx.doi.org/10.1007/BF02897707

[37] WHO, World Health Organization (2008) Guidelines for Drinking-Water Quality. http://www.who.int/entity/water_sanitation_health/dwq/GDW9rev1and2.pdf

[38] Reale, M. (2001) Preliminary Lessons of Law. 25th Edition, Saraiva, São Paulo. (In Portuguese)

[39] Reale, M. (2002) Law Philosophy. 19th Edition, Saraiva, São Paulo. (In Portuguese) 
Scientific Research Publishing (SCIRP) is one of the largest Open Access journal publishers. It is currently publishing more than 200 open access, online, peer-reviewed journals covering a wide range of academic disciplines. SCIRP serves the worldwide academic communities and contributes to the progress and application of science with its publication.

Other selected journals from SCIRP are listed as below. Submit your manuscript to us via either submit@scirp.org or Online Submission Portal.
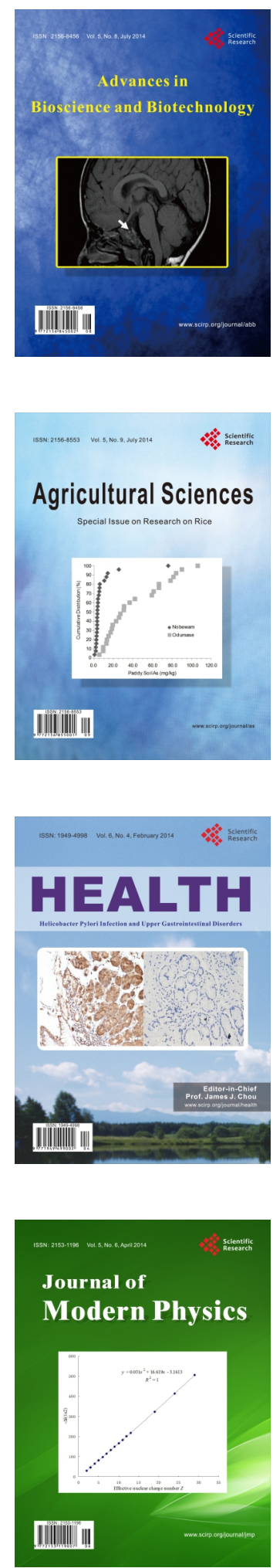
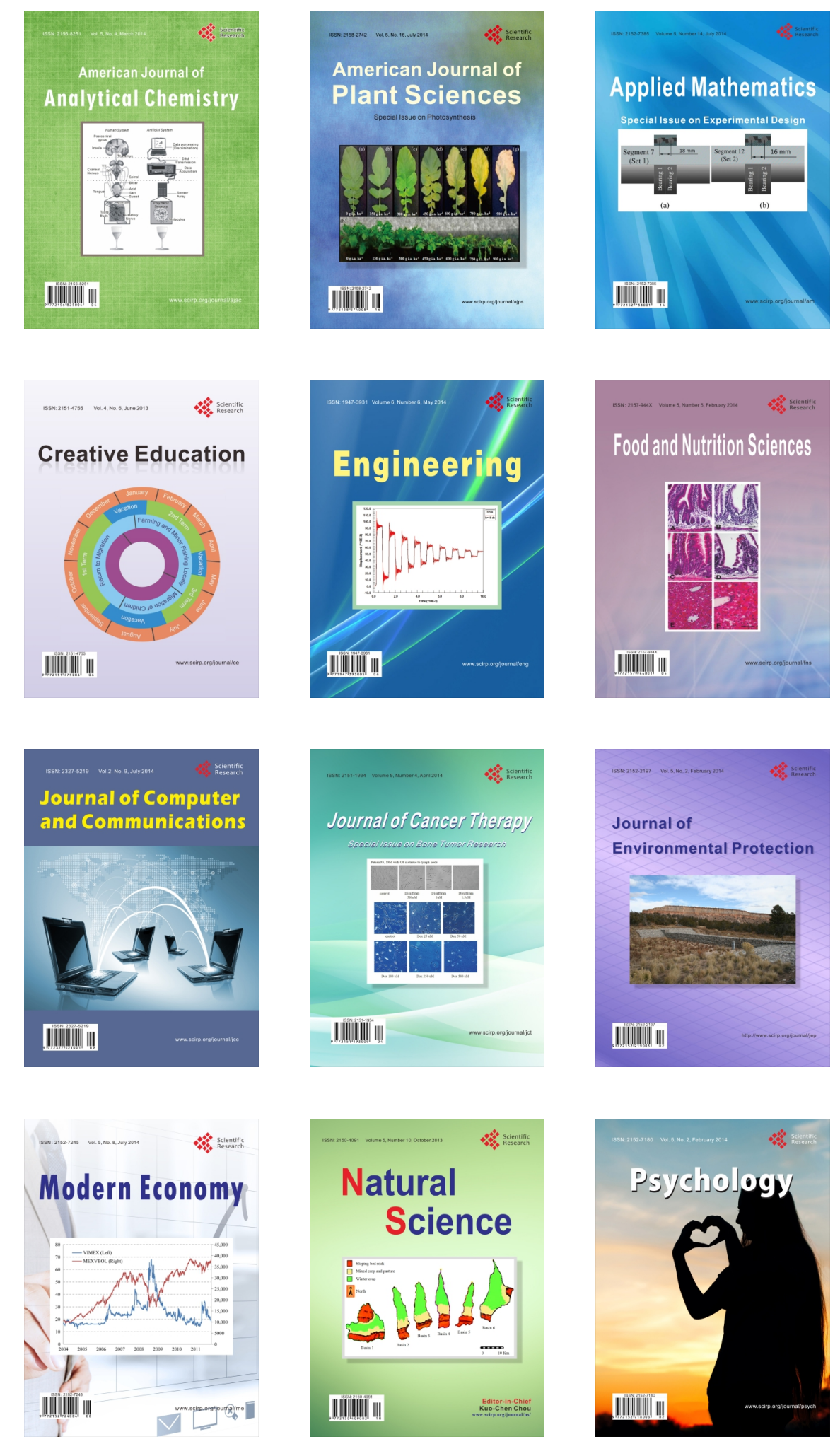